\title{
Impact of Lapindo Hot Mud Flowing on Macrozoobenthos Communities in Estuary Porong, East Java
}

\author{
${ }^{1}$ Tarzan Purnomo, ${ }^{2}$ Fida Rachmadiarti \\ Department of Biology \\ Faculty of Mathematics and Natural Sciences \\ Universitas Negeri Surabaya \\ Surabaya, Indonesia \\ tarzanpurnomo@unesa.ac.id
}

\author{
${ }^{3}$ Soegiyanto \\ Department of Geography \\ Faculty of Social Sciences and Law, \\ Universitas Negeri Surabaya \\ Surabaya, Indonesia
}

\begin{abstract}
Estuary Porong is part of the east coast of Sidoarjo, East Java, which receives the Lapindo mudflow. Lapindo mudflow into the sea through the Porong river has caused sedimentation and changed the Porong river base substrate morphology so that it affects the organism that live in the estuary, especially macrozoobenthos because of their habitat on the bottom substrate. This study aims to identify the types of macrozoobenthos that live in the waters of Estuary Porong after the Lapindo mudflow. This research was conducted by observation method with sampling at 7 stations in Estuary Porong, Sidoarjo with purposive sampling method. Data collection was carried out at the end of the dry season using the Petersen grab sediment-taking tool. Identification of the types of macrozoobenthos is carried out in the Laboratory of Ecology, Department of Biology FMIPA Universitas Negeri Surabaya to species level. The research parameters measured included water quality, types of macrozoobenthos, $\mathrm{Pb}$ metal content in water and macrozoobenthos. Data were analyzed descriptively quantitative and qualitative. The results showed that in Porong estuary, 22 species of macrozoobenthos were found. The dominant and adaptive species to conditions covered by Lapindo mud are Potamocorbula faba, Chironomus sp., Varuna yui, and Mictyris platycheles. There is a relationship between $\mathrm{Pb}$ levels in water and $\mathrm{Pb}$ levels in macrozoobenthos.
\end{abstract}

Keywords-Porong estuary; biodiversity; makrozoobentos; lapindo mud

\section{INTRODUCTION}

Estuary Porong is part of the eastern coastal region of Sidoarjo Regency, East Java. The characteristics of the Porong estuary, namely the land surface height is almost the same as the average sea level with an elevation of 1-1.5 meters. The topography of the sloping and shoreline is lower than the tide surface, causing the movement of river water at high tides and even tends to move ashore to fill the area of farms and rice fields. In addition, the movement of parallel longshore currents from west to east, wave height between 0.5-2 meters, plays a role in transporting sediment [1]. Substrate estuary

Porong is generally sedimentary mud and overgrown with mangroves. Land is used as a farming land by the community.

The waters of these estuaries are rich in nutrients and micro-organisms as natural food, so this area is usually a nursery area and an area for feeding ground for various types of marine organism [2]. The supply of organic material from the river flow and nutrients from the wave movement from the sea makes the estuary of the fertile area [3]. Thus estuary is an aquatic ecosystem that has a very good carrying capacity for marine life and river life. Therefore, it has greater biodiversity compared to the sea and rivers [4].

Benthos is an organism that lives on the surface of the waters and or in aquatic sediments [5]. One of the functions of benthos in the aquatic food chain is as detritus feeder. Thus the absence of benthos in an aquatic ecosystem will be rooted in the flow of energy and the material cycle in estuaries, rivers and seas [4]. Because of its low mobility or sessile ability, benthos cannot avoid the negative effects of its environment, such as heavy metals. Benthic organism can be used as bioindicators of the quality of polluted waters because their benthic are settled or attached to the bottom of the waters so that they can be used to describe the condition of a waters [6].

Based on the results of an analysis at the Mineral and Coal Chemical Testing Laboratory, Center for Geological Resources, Bandung [7], Lapindo mud water contains various heavy metals. Of the 12 types of metals in Lapindo mud water whose levels are above the threshold value of the quality standard [8] [9], namely cadmium ( $\mathrm{Cd})$, lead $(\mathrm{Pb})$, Mangaan $(\mathrm{Mn})$ and Ferum $(\mathrm{Fe})$, while in sediments, from 14 types of metal, the levels above the threshold value of the quality 
standard are 10 types, namely $\mathrm{Cd}, \mathrm{Cu}, \mathrm{Pb}, \mathrm{Hg}, \mathrm{Se}, \mathrm{Cr}, \mathrm{Zn}, \mathrm{Mn}$, $\mathrm{Ag}$, and $\mathrm{Sb}$.

Lapindo mud contains heavy metals because of the high temperature of mud due to the influence of geothermal activity, it can dissolve the trace elements hydrothermal solution. Trace elements commonly contained in hydrothermal solutions are $\mathrm{Cu}, \mathrm{Pb}, \mathrm{Zn}, \mathrm{Mn}, \mathrm{Fe}, \mathrm{Cd}, \mathrm{As}, \mathrm{Sb}, \mathrm{Au}, \mathrm{Hg}$, Tl, and Se [7]. If these metals are present in nature, the potential to enter the food chain system is difficult to avoid [10]. One of the most dangerous heavy metals in lapindo mud is lead $(\mathrm{Pb})$, because it is very toxic, especially in the nervous system, hemetologic, hemetotoxic and affect kidney performance. In humans the main source of lead is food and drinks that contain lead. Weekly consumption of this element is recommended by WHO for its tolerance for adults $50 \mu \mathrm{g}-\mathrm{kg}$ of body weight and for infants or children $25 \mu \mathrm{g}$-kg of body weight [11].

The drainage of lapindo mud into the Madura Strait through the Porong River has caused sedimentation changes in the Porong river and estuary Porong [12]. Thus it is necessary to assess the impact on the macrozoobenthos community in the estuary and east coast of Sidoarjo. The purpose of this study was to determine the impact of Lapindo mud on macrozoobenthos diversity in Estuary Porong Sidoarjo Regency, East Java.

\section{MATERIALS AND METHODS}

The study was conducted in Porong estuary at the end of the dry season, in August. Sampling was carried out at 10.0011.30 PM when the coastal water receded the furthest, which was $-120 \mathrm{~cm}$. Macrozoobenthos samples were taken at 7 (seven) stations which were determined purposively, namely station $1\left(07^{\circ} 32^{\prime} 29.0^{\prime \prime} \mathrm{LS}, 112^{\circ} 50^{\prime} 26.0^{\prime \prime} \mathrm{BT}\right)$, station $2\left(07^{\circ}\right.$ 33 '32.2 "LS, $112^{\circ} 51$ '21,6 "BT), station 3 (07 32' 01,3" LS, $112^{\circ} 51$ '07,6 "BT), station 4 (07³3'53,9" LS, 112 ${ }^{\circ} 52^{\prime}$ '05, 5 "BT) station $5\left(07^{\circ} 32\right.$ '05.5" LS, $112^{\circ} 52^{\prime} 13.9^{\prime \prime}$ "BT), station 6 $\left(07^{\circ} 32\right.$ '10.5" LS, $112^{\circ} 52^{\prime} 23.9$ "BT), and station $7\left(07^{\circ} 32\right.$ '21.5 "LS, $112^{\circ} 52^{\prime}$ '43.7" BT). Macrozoobenthos identification was conducted at the Biology Department's Taxonomy Laboratory, Surabaya State University. Taking macrozoobenthos samples using Petersen grab measuring $20 \mathrm{x}$ $20 \mathrm{~cm}$ weight $20 \mathrm{~kg}$, collection bottles, plastic bags, label paper, $0.5 \mathrm{~mm}$ mess sieve; while the material used is $70 \%$ alcohol. Macrozoobenthos were taken by dredging the base substrate using Petersen grab, sludge and macrozoobenthos taken by subsample by 0.25 Petersen grab [6]. After that the macrozoobenthos are cleaned, by means of sludge and macrozoobenthos which are taken into a bucket in which a 0.5 $\mathrm{mm}$ filter cloth is doused with water several times until clean. Macrozoobenthos collected in a filter cloth are taken with tweezers and put into a collection bottle containing 70\% alcohol. Macrozoobentos is identified based on [13] [14].

\section{RESULTS AND DISCUSSION}

\section{Macrozoobenthos Community of Estuary Porong}

Based on the results of the identification, macrozoobenthos found in Estuary Porong Sidoarjo consisted of 22 species distributed at 7 stations as in Table 1.

TABLE I. MACROZOOBENTHOS DIVERSITY AND DENSITY IN ESTUARY PORONG AFTER LAPINDO MUDFLOW

\begin{tabular}{|l|l|l|l|l|l|l|l|l|}
\hline \multirow{2}{*}{ Species } & \multicolumn{7}{c|}{ Amount species at station } & \multirow{2}{*}{ Ind. } \\
\cline { 2 - 8 } & I & II & III & IV & V & VI & VII & \\
\hline Littorina scraba & 9 & & & & 6 & 11 & 14 & $\mathbf{4 0}$ \\
\hline Littorina melanostoma & & 2 & 14 & 9 & 11 & 6 & & $\mathbf{4 0}$ \\
\hline Littoraria articulate & & & 7 & & 8 & & & $\mathbf{1 5}$ \\
\hline Mictyris platycheles & 17 & 2 & & & & 6 & 19 & $\mathbf{4 4}$ \\
\hline Varuna yui & 6 & 6 & 7 & & 27 & 7 & 7 & $\mathbf{6 0}$ \\
\hline $\begin{array}{l}\text { Episesarma } \\
\text { palawanense }\end{array}$ & 6 & & & 7 & & & 6 & $\mathbf{1 9}$ \\
\hline Episesarma mederi & 6 & & & & & 7 & 7 & $\mathbf{2 0}$ \\
\hline Episesarma versicolor & & 5 & & & & 6 & 6 & $\mathbf{1 7}$ \\
\hline Metaplax elegans & 7 & 6 & & & 7 & 7 & 6 & $\mathbf{3 3}$ \\
\hline Ocypode cordimanus & 5 & & 6 & & 7 & & 6 & $\mathbf{2 4}$ \\
\hline Merapenaeus affinis & 6 & & & & & & 7 & $\mathbf{1 3}$ \\
\hline Uca tetragonon & & 5 & & & & 6 & & $\mathbf{1 1}$ \\
\hline Theora lata & & 6 & & 5 & & 7 & & $\mathbf{1 8}$ \\
\hline Chironomus sp & 3 & 11 & 21 & & 23 & 13 & 4 & $\mathbf{7 5}$ \\
\hline Nereis sp & 1 & 6 & & 7 & & 7 & 5 & $\mathbf{2 6}$ \\
\hline Natica sertata & & 7 & & 15 & & 6 & 2 & $\mathbf{3 0}$ \\
\hline Nassarius leptospirus & & & & 7 & & & & $\mathbf{7}$ \\
\hline Heliacus variegates & & & 6 & & 7 & & 1 & $\mathbf{1 4}$ \\
\hline Fissilabia sp. & & & 7 & & 7 & & & $\mathbf{1 4}$ \\
\hline Nerita albicilla & & & 5 & & 6 & & 4 & $\mathbf{1 5}$ \\
\hline Potamocorbula faba & & 2 & & 31 & 30 & 8 & 5 & $\mathbf{7 6}$ \\
\hline Mactra queenslandica & & & 2 & 6 & & 4 & 2 & $\mathbf{1 4}$ \\
\hline & $\mathbf{1 0}$ & $\mathbf{1 1}$ & $\mathbf{9}$ & $\mathbf{8}$ & $\mathbf{1 1}$ & $\mathbf{1 4}$ & $\mathbf{1 6}$ & \\
\hline
\end{tabular}

Of the 22 macrozoobenthos species found in Porong estuary, the highest density were Potamocorbula faba (76), Chironomus sp., (75) varuna yui (60), Mictyris platycheles (44), Littorina scraba (40), and Littorina melanostoma (40). This shows that sucked species are able to live in sedimentary conditions from lapindo mud deposits. Differences in diversity and density of macrozoobenthos are also seen between stations. Of the 7 data collection stations, the least members of the macrozoobenthic community were at station 4 (8 species with 87 individual densities), namely Littorina melanostoma, Potamocorbula faba, Natica sertata, Nereis sp., Mactra queenslandica, Theora lata, Nassarius leptospirus, and Episesarma palawanense. This is possible because station 1 is the main one getting Lapindo mudflow. While the most abundant is at station 7 (16 species with 99 individual densities), because this station is the furthest from the mouth of the Porong estuary as input for the entry of lapindo mud into the sea waters in the Madura strait [15]. The difference in macrozoobenthic community structure in the Porong estuary was also influenced by the quality of estuary waters [16] as shown in Tables 2 and 3. 
2. Water Quality of Estuary Porong, Eastern Coastal Sidoarjo

TABLE II. VAlue of THe Physical AND Chemical Parameters of WATERS IN ESTUARY PORONG

\begin{tabular}{|l|l|c|c|c|c|c|c|c|}
\hline \multirow{3}{*}{ Parameter } & \multicolumn{7}{|c|}{ Station and value } & $\begin{array}{c}\text { QS } \\
{[8]}\end{array}$ \\
\cline { 2 - 9 } & $\mathbf{1}$ & $\mathbf{2}$ & $\mathbf{3}$ & $\mathbf{4}$ & $\mathbf{5}$ & $\mathbf{6}$ & $\mathbf{7}$ & \\
\hline Salinity (\%) & 25 & 25 & 29 & 28 & 23 & 23 & 23 & 0.5 \\
Temperature & 29.6 & 31 & 31.3 & 32 & 29.7 & 29 & 29 & Dev. 3 \\
$\mathrm{pH}$ & 7.5 & 7.6 & 7.6 & 7.6 & 7.1 & 7.4 & 7.4 & $6-9$ \\
$\mathrm{DO}(\mathrm{ppm})$ & 1.2 & 1.1 & 1.3 & 1.8 & 2.4 & 2.5 & 2.5 & 3 \\
$\mathrm{CO}_{2}(\mathrm{ppm})$ & 20.0 & 22.1 & 20.2 & 20.1 & 19.3 & 18.6 & 17.8 & $33^{* * *}$ \\
\hline
\end{tabular}

Note: QS=Quality standard

\section{Water Quality of Porong River}

TABLE III. CHARACTERISTICS OF THE PORONG RIVER PHYSICOCHEMICAL PARAMETERS AFTER THE LAPINDO MUDFLOW

\begin{tabular}{|l|l|l|l|l|}
\hline \multirow{2}{*}{ Parameter } & \multicolumn{3}{|l|}{ Station and value } & $\begin{array}{l}\text { Quality of } \\
\text { Standard } \\
\end{array}$ \\
\cline { 2 - 4 } & $\mathbf{1}$ & $\mathbf{2}$ & $\mathbf{3}$ & \\
\hline Salinity $(\%)$ & 0.06 & 20 & 20 & 0 \\
Temperature $\left({ }^{\circ} \mathrm{C}\right)$ & 27.6 & 32 & 30 & Dev. 3 \\
pH & 7.6 & 8.4 & 8.3 & 7.7 \\
$\mathrm{DO}(\mathrm{ppm})$ & 1.32 & 0.00 & 0.36 & 5 \\
$\mathrm{CO}_{2}(\mathrm{ppm})$ & 12.90 & 24.67 & 28.15 & 0.75 \\
\hline
\end{tabular}

Note: Station 1: Village Manggung, 2: Village Pejarakan, 3: Village Bangun Sari.

Table 1-3 above shows that there have been changes in the physical-chemical parameters of the waters on the east coast of Sidoarjo, especially water salinity. Water salinity indicates the characteristics of marine waters ( this estuary area is a brackish water ecosystem. This happened because of the entry of Lapindo mud water with high maternity (32-40\%) [12]. As a result of the mud flow containing various organic materials and heavy metals, the temperature and $\mathrm{pH}$ of the water is high, but the dissolved oxygen is low.

The decline in water quality due to contamination with Lapindo mud has caused degradation of aquatic organism composition [12]. This is because Lapindo mud contains various elements that are harmful to aquatic organism, including high salinity and heavy metals. This difference is due to changes in the base substrate and the high turbidity of the water. The high sedimentation and turbidity of the water, causing changes in benthic microhabitat [17] [18]. The most striking change is the base substrate which was originally gravel and sand textured, after the entry of the mud turns into mud and sand which tend to be anaerobic [19].

\section{Lead $(\mathrm{Pb})$ Levels in Macrozoobenthos}

One of the elements contained in Lapindo mud is heavy metal [20]. Among the heavy metals contained in Lapindo mud the highest levels [21]. Therefore, the entry of Lapindo mud into Porong estuary will cause contamination of estuary water by heavy metals which will eventually be accumulated by macrozoobenthos (Figure 1).

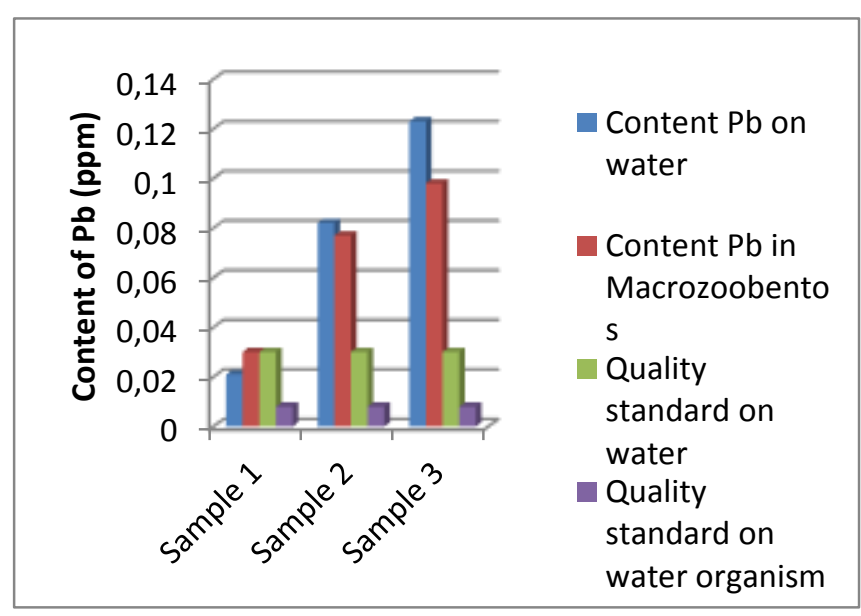

Fig 1. Histogram content of lead (ppm) in water, macrozoobenthos Porong estuary and quality standards after the Lapindo mudflow

The measurement results show that there is a correlation between the levels of lead $(\mathrm{Pb})$ in estuary Porong river with lead levels in macrozoobenthos, ie the higher the $\mathrm{Pb}$ level in water the higher the level in macrozoobenthos (Figure 2). Thus heavy metal lead has the potential to enter the estuary and sea food chains on the east coast of Sidoarjo [20].

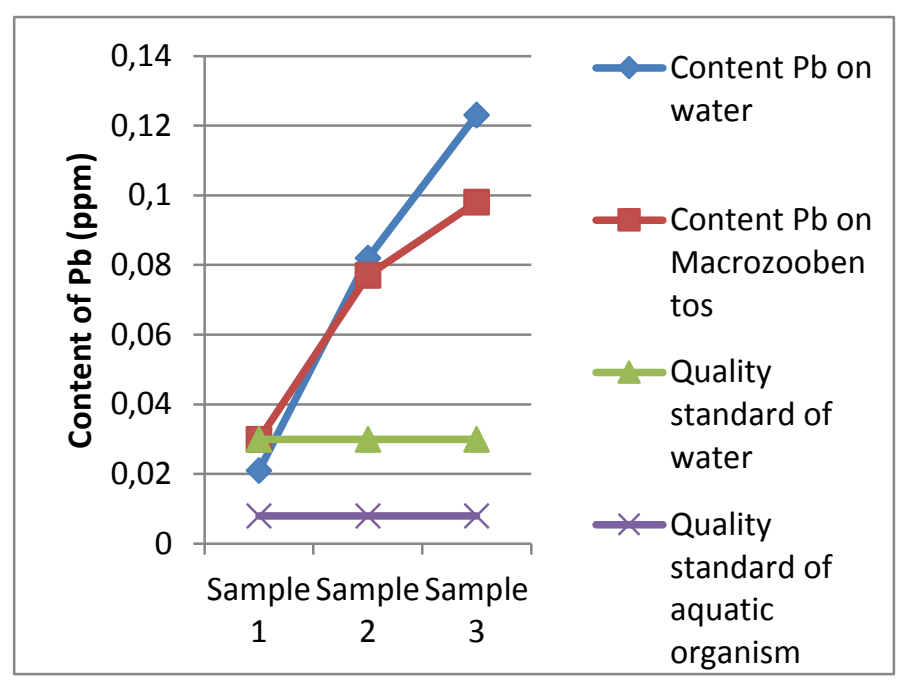

Fig 2. The relationship between lead levels (ppm) in water Porong estuary and the lead levels macrozoobenthos after Lapindo mudflow

Based on the results of research conducted, macrozoobenthos were found in the estuary Porong, Sidoarjo on 7 stations consists of 22 species, the Littorina scraba, Varuna yui, Episesarma Palawanense, Episesarma mederi, Mictyris platychele, Metaplax elegans, Ocypode cordimanus, Merapenaeus affinis, Episesarma versicolor, Uca tetragon, Theora lata, Chironomus sp., Nereis sp, Natica sertata, Littorina melanostoma, Littoraria Articulata, Heliacus variegated, Fissilabia sp., Nerita albicilla, Potamocorbula faba, Mactra queenlandica, and Nassarius leptospirus.

At station 1 the most dominant species is Mictyris platycheles. Mictyris is the only genus in the Mictiridae Family in the western Pacific, Indonesia and Australia. 
Mictyris platycheles dominate in the area of Victoria Australia, this species congregate in large numbers on the surface of the water when the sand at low tide [22]. Research conducted Warwick et all., [23] in Eaglehawk Neck, Tasman Peninsula, Tasmania showed that the activities of eating and revolving committed by Mictyris platycheles interrupt habitat meiobenthic in it because of the substrate which is occupied Mictyris platychel be different from the substrate that does not exist Mictyris platycheles in which the substrate with no Mictyris platycheles is finer.

At station 2 and station 3, the dominant species are Chironomus sp. found in the larval phase. Sastrawijaya [24] states that Chironomus sp. is an invertebrate macro animal which is an indicator of organic pollution in the category of aggressively heavily polluted. The existence of Chironomus sp. signify various activities for internal activities by the surrounding community. Chironomus sp. looks tolerant and has good osmoregulation capabilities, these entities can adjust to the extreme conditions that surround them [25].

At stations 4 and 5, Potamocorbula faba is the most dominant species. Research conducted by Ambarwati and Trijoko [26] on the coastal coast of Sidoarjo shows that during the sampling period, Potamorbula faba is the only shellfish that can be found in very high densities, namely 3,549-10,000 individuals $\mathrm{m}^{-2}$. Several factors can cause this condition to be wrong because the estuary area of the Kepetingan River is in an unharmonious condition from organic and inorganic pollution. In polluted environments, only resistant groups can survive and multiply. Unique morphological characters Potamocorbula faba supports critical life in extreme environments [27]. Spotted forms with tightly closed connections, can protect themselves during extreme conditions such as extreme salinity. These shells have gill eulamelibrancia also support suspension feeders. The existence of sucking retractile and supports developing activities.

At stations 6 and 7 the most dominant is Littorina scraba this is possible because at this time there are a lot of organic material sourced from the flow of the Porong river that enters the waters of the Madura Strait. Given that macrozoobenthos are detritus decomposers that inhabit estuaries.

The entry of Lapindo mud into Porong estuary has caused contamination of estuary water by heavy metals which can be terminated by macrozoobenthos (Figure 1). There is truth between the levels of lead $(\mathrm{Pb})$ in estuary Porong river with lead levels in macrozoobenthic, ie the higher the $\mathrm{Pb}$ level in water the higher the macrozoobenthic (Figure 2). The entry of heavy metals into the estuary and sea food chains on the east coast of Sidoarjo is very potential [28]. This is what will be a threat to food security in the eastern region of Sidoarjo [20].

\section{CONCLUSION}

Based on the results of the study showed that the Lapindo mudflow to the sea through Porong river has reduced water quality, especially salinity, DO, and $\mathrm{CO} 2$, which has a negative impact on macrozoobenthos diversity and density in Porong Estuary. In the Porong estuary, only 22 macrozoobenthos species were dominated by Potamocorbula faba, Chironomus sp., Varuna yui, and Mictyris platycheles. The farther from the mud flow the macrozoobentgos density is higher. Macrozoobenthos have been contaminated with lead, the indication of lead content in macrozoobenthos has exceeded the quality standard threshold.

\section{REFERENCES}

[1] D.M. Paterson, "Short-term changes in the Erodibility of Intertidal cohesive sediments related to the migratory behavior of epipelic diatoms". Limnol Oceanogr, vol. 34, pp. 223-234, 1989.

[2] J. Nybakken, Marine Biology: An Ecological Approach. Jakarta: PT. Gramedia Pustaka Utama, 2001.

[3] G.A. Knox, Estuarine Ecosystem: A System Approach. Florida: CRC Press, 1986.

[4] R.E. Sherman, "Habitat change in estuarine: Predicting Broad- scale responses of intertidal macrofauna to sediment content". Marine Ecology Progress Series. vol. 263. pp 101 - 112, 2003.

[5] M. Kordi and H. Ghufran, Water quality parameters. Surabaya: Your work, 1996.

[6] A. Soegianto, Methods for Estimating Water Pollution with Biological Indicators. Surabaya: Airlangga University Press, 2004.

[7] BPLS, Research Result of Environmental Study of the Geological Agency of the Department of Energy and Mineral Resources. Surabaya: Sidoarjo Mudflow Management Agency, 2007.

[8] PP RI No. 82, Concerning Management of Water Quality and Water Pollution Control, 2001.

[9] Governor East Java No. 45, Decree of the Governor of East Java No. 45.2002. Regarding Water Quality Management and Water Pollution Control. Surabaya: East Java Regional Government, 2002.

[10] G. J. Benyehuda, P.L. Coombs, D. Ward, Balkwill and T. Barkay, "Metal Resistance Among Aerobic Chemoheterotrophic Bacteria From The Deep Terrestrial Subsurface”. Botanica, vol. 46, pp. 7-18, 2004.

[11] Suhendrayatna, Bioremoval Heavy Metal Using Microorganisms: A Literature Study (Haevy Metal Bioremoval By Microorganisms: A Literature Study). Paper Presented at the 21st Century Biotechnology On Water Seminar for February 1 - 14, 2001. Sinergy Forum - PPI Tokyo Institute of Technology, 2001.

[12] T. Purnomo, Lapindo mud sedimentation and its effects on the community of Porong plankton and aquatic insects. Proceedings of the National Science and Education Seminar and Workshop. December 13, 2008, Department of Biology Faculty. MIPA Surabaya State University, 2008.

[13] B. Dharma, Recent and Fossil Indonesian Shell. Hackenheim: Conchbooks, 2005.

[14] K.E. Carpenter and H.N. Volker, The Living Marine Resources of the Western Central Pacific. Rome: Food and agriculture organization of the United Nations, 1998.

[15] T. Purnomo, The Impact of Lapindo Mud on the Quality of East Coast Ecosystems in Sidoarjo, East Java. National Conference on Management of Coastal, Marine and Small Islands Resources (KONAS IX). November 19-22 2014, JW Marriot Hotel Surabaya, 2014.

[16] K.J.M. Kramer, Tidal Estuaries: Manual of Sampling and Analittycal Procedure. AA Balkema, 1994.

[17] Sahirman, Diversity and Distribution of Molluscs in Forest Areas Mangrove Nusa Karang Kobar Segara Anakan Cilacap Regency, Essay. Faculty of Biology. UNSOED, Purwokerto, 1997.

[18] Mendeley, Distinction between sorttable sits aggregated particles muddy intertidal sediments. http://www.mendeley.com/researc $\mathrm{h} /$ distinction-between-sortable-silts-aggregated-particles-muddyintertidal-sediments-east-frisian-wadden-sea-southern-north-sea-1/\#: east Frisian wadden sea southern north sea, 2007. 
[19] Geological Sediments 202, Tidal Basins www.elsevier.com 453-463/ search / sedgeo //. html., 2007.

[20] T. Purnomo and F. Rachmadiarti, "The Changes of Environtment and Aquatic Organism Biodiversity in east coast of sidoarjo Due to Lapindo Hot Mud". Int. J. of GEOMATE. vol. 15, 2018.

[21] T. Purnomo, Biodiversity of aquatic Organism and Heavy Metal Content in Waters and aquatic Organism as The Impact of Lapindo Mud Volcano. Proceeding International Conference on Biological Science (ICBS). 16-17 Oktober 2009, the Faculty of Biology, University of Gadjah Mada, Jogjakarta, 2009.

[22] P. Gary and T.A. Shane, Marine Decapod Crustacea of Southern Australia. Collingwood: CSRIO Publising, 2004.

[23] R.M. Warwick, K.R Clarke and J.M. Gee, The Effect of Disturbance by Soldier Crabs Mictyris platycheles H. Milne Edwards on Meiobenthic Community Structure, J. of Exp. Marine Biology and Ecology, vol. 135, pp. 19-33, 1990.
[24] A.T. Sastrawijaya, Environmental Pollution. Jakarta: Rineka Cipta, 1991.

[25] L.R. Kawuri, N.S. Mustofa and Suryanti, "Aquatic Conditions Based on the Macrozoobenthos Bioindicator in the River At the Scratch of Semarang City”. J. Mgmt. of Aquatic Resources, vol. 1, pp 1-7, 2012.

[26] R. Ambarwati and Trijoko, Morphological Characteristics of Suspension Feeder Bivalve Potamocorbula faba (Bivalvia: Corbulidae). Proceeding of the International Conference of Biological Science Faculty of Biology, Gajah Mada University, 2011a.

[27] R. Ambarwati and Trijoko. Functional Morphology of Deposit Feeder Bivalve Theora lata (Bivalvia: Semelidae). Proc. of Int. Con. on Basic Science. Brawijaya University, 2011b.

[28] E.G. Yusung, The Ecology of natural disturbance and patch dinamics. Florida: Academic Press Inc, 1999, pp 3-4. 